\title{
Studies of the Effect of Vinegar Ingestion after the Strenuous Wingate Test on Energy Substrates during Recovery Periods
}

Young Ju Song and Sungpil Ryu ${ }^{1 *}$

Division of Sports Science, College of Health Science, Sunmoon University, Asan 336-708, Korea

${ }^{1}$ Department of Leisure Sports, College of Ecology and Environmental Science, Kyungpook National University, Sangju 742-711, Korea

Received May 28, 2010 / Accepted September 13, 2010

\begin{abstract}
We investigated the effect of brown-rice vinegar (BRV) ingestion after strenuous Wingate tests on energy substrates during a $2 \mathrm{hr}$ recovery period. For this, seven healthy male adolescents were chosen as subjects. They performed 3 Wingate tests to induce fatigue, after which they ingested brown-rice vinegar (BRV) drink and/or water as a control $(\mathrm{CON})$ after $15 \mathrm{~min}$ of the test. Blood was obtained pre-exercise and $30 \mathrm{~min}, 60 \mathrm{~min}$, and $120 \mathrm{~min}$ post-exercise, and blood glucose, lactate, free fatty acids, ammonia, and cortisol were analyzed. After $120 \mathrm{~min}$ of recovery period, the 4th Wingate test was conducted to calculate the power recovery ratio of the 3rd and 4th trials. Breathing frequency, oxygen saturation, and heart rate did not show significant changes. Blood glucose level was lower in CON than BRV after 120 min of recovery, and blood lactate and ammonia levels were lower in BRV at 60 and $120 \mathrm{~min}$. The higher free fatty acids were found at 60 and $120 \mathrm{~min}$ in BRV. In addition, Wingate power recovery ratio of peak power and peak power/body weight was significantly higher in BRV compared to CON. These results suggested that BRV ingestion after strenuous exercise facilitates fatigue recovery. Therefore, BRV might be effectively used as an ergogenic aid for events in which competitors compete two or more times a day.
\end{abstract}

Key words : Brown-rice vinegar, Wingate test, fatigue recovery, energy metabolism

\section{서 론}

피로회복은 단순하게 운동능력의 증진뿐만 아니라 개인의 건강증진 및 개선에도 매우 중요할 것이다. 실제로 규칙적인 운동을 하는 경우에도 운동에 의해 유발된 피로에 의하여 우 울증 유발과 삶의 질 점수가 낮게 유지되며[34], 말초피로에 의한 신경근 장애 유발 및 부상의 위험성이 증대된다[1,13]는 점을 고려해 볼 때, 피로회복은 매우 필요하여 운동 훈련 후에 나타나는 피로의 회복 촉진을 위해 다양한 연구가 시도되고 있다.

운동성 피로회복 또는 발생 지연을 위해 선택하는 방법으로 는 가벼운 유산소성 운동에 의한 회복[3], 손바닥 냉각[23], 마 사지[24] 등에 관한 연구와 최근에는 운동에 의한 피로를 지연 또는 억제시킬 수 있는 영양보조물에 대한 연구가 지속적으로 이루어지고 있다[11,28,31]. 실제로 항피로효과가 있는 영양보 조물의 섭취로 인하여 운동에 의해 유발된 근피로가 억제되었 다는 보고도 있다[38].

한편, 건강에 관한 관심의 증가에 대한 요구에 부응하기 위하여 건강식품의 개발과 판매가 확대되고 있다. 특히 비타 민, 미네랄 등 미량 영양소의 제한적인 판매가 이루어졌던

\section{*Corresponding author}

Tel : +82-54-530-1434, Fax : +82-54-530-1434

E-mail : ryusp@knu.ac.kr
과거와는 달리, 최근에는 식품으로서의 기능성을 추구하고 자 하는 현상이 나타나고 있다. 우리나라는 오래 전부터 발 효과정을 거친 식초를 섭취하고 있었으며, 최근에는 건강 기 능성 식품으로서 광고 및 공중파에서도 건강증진에 효과가 있는 것으로 알려지면서 소비가 증가되고 있다. 그 효과로서 는 피로회복 촉진[15], 혈중지질 감소[16], 식욕억제[27] 효과 등이 보고되고 있으며, 지구성 운동시 지방산화의 증대의 결 과도 나타나고 있다[30]. 이러한 식초의 주성분은 초산이 대 부분이며[20], 다양한 아미노산과 미네랄 역시 포함하고 있 다[18]. 초산은 간과 골격근의 대표적인 두 조직에서 phosphofructokinase type I, II의 활성을 억제하는 작용을 하기 때문에 초산의 탄수화물 산화 억제 효과를 고려할 때 $[33,35]$ 운동에 의해 유발되는 피로의 회복을 촉진하는 기능성 식품 으로서의 효과가 있을 것이라 생각되며, 식초섭취에 의하여 지구성 운동 중에 자각적 피로도가 유의하게 낮았다는 선행 연구도 있다[30]. 초산은 단쇄지방산이 일종으로서 식이를 제한하더라도 조직 내의 PFK-I의 활성을 억제하여 해당과정 을 억제하는 작용을 한다[15].

운동과 관련된 기능성 식품으로서의 활용도를 증대시키기 위하여 다양한 방법으로 검증이 필요하며[30], 다양한 종류의 식초가 판매되고 있는 현실을 감안할 때 운동선수뿐만 아니라 운동을 즐기는 일반인의 운동성 피로의 회복촉진 관련 연구는 천연식품으로서의 식초의 우수성을 인정받는데 필요하다고 
할 수 있다. 따라서 본 연구에서는 식초가 고강도의 탈진적인 윙게이트 테스트 후 회복기의 에너지 기질 이용의 회복에 미 치는 영향을 조사함으로써 기능성 식품뿐만 아니라 영양보조 물로서의 가능성을 제시함으로써 천연식품의 이용증대와 운 동에 참여하고 있는 개인에게 다양한 선택을 할 수 있는 자료 를 제공하고자 한다.

\section{재료 및 방법}

\section{연구대상}

신체적으로 건강한 체육학과 재학생 남자 7명을 피험자로 선정하였다. 피험자들은 최소한 3 개월 이전에 어떠한 약물 복 용 전력이 없었으며, 건강보조식품을 섭취하지 않았으며, 실 험기간 중에도 섭취를 하지 않도록 교육하였다. 이들은 정규 수업 교과목 이외에 약 1 시간 정도의 자발적인 운동을 2 개월 정도 실천하고 있었고, 엘리트 운동선수의 경험이 없는 상태 였으며, 흡연을 하지 않는 피험자로 구성되었다. 피험자들은 실험에 참가하기 전에 본 실험의 목적과 방법에 대한 교육을 받았으며, 실험의 중요성과 위험성에 대한 설명을 듣고 실험 참가 동의서를 제출하였다. 피험자들의 신체적 특징은 Table 1 과 같다.

\section{실험진행}

피험자들은 12 시간 이상의 공복을 유지한 상태에서 윙게이 트 테스트 2시간 전에 실험실에 도착하여 용변을 본 후 피험자 의 양 손과 발을 전해질 티슈로 청결하게 하고, 8 개의 극점에 정확하게 위치할 수 있도록 지도한 후 체성분 분석기(InBody 720 , 바이오스페이스, 대한민국)를 사용하여 체지방률을 분석 하였다. 그 후 안정상태에서 $300 \mathrm{kcal}$ 의 균형영양식(단백질 $20 \%$, 지방 $25 \%$, 탄수화물 $55 \%$; 메디푸드 1.5 , 한국메디칼푸드, 대한민국) 2 개를 섭취하여 섭취영양소에 대한 간섭을 최소화 하였다. 1 시간 30 분의 안정상태를 유지한 후 10 분간 가벼운 스트레칭으로 준비운동을 실시하였다.

윙게이트 테스트기(Excaliber Sport, Sweden)를 이용한 테 스트를 실시하기 직전 안정상태에서의 혈액을 상완주전정맥 에서 $10 \mathrm{cc}$ 채혈하였다. 각각의 피험자의 하지길이와 무릎 각 도를 맞춘 후 기록하여 2차 실험 시에도 동일하게 적용하였다. 우선 안장의 높이를 맞추고 상체의 기울기를 일정하게 하기 위하여 손잡이의 거리를 조절한 후 페달에 발을 고정시킨 후
2 분간 워밍업을 실시하였다. 이후 30 초간 $50 \mathrm{rpm}$ 으로 운동을 하면서 시작 5 초 전부터 마이너스 카운트를 하여 30 초가 되었 을 때 [시작]이라는 구두신호와 함께 30초간 최대한 빠르게 실시하여 5 초 간격으로 축의 회전 수를 기록하였다. 또한 30 초 의 전력운동이 끝난 후 30 초의 휴식이 이어졌으며, 다시 동일 한 반복운동을 하는 것을 3 회 실시한 선행연구를 응용하여 적용하였다[3]. 또한 테스트 2시간 후 회복기의 변화를 조사하 기 위하여 동일한 방법으로 4 회째의 윙게이트 테스트를 부하 하였다. 이때의 운동능력은 컴퓨터와 연결되어 자동 측정되었 으며, 최대파워, 평균파워 등을 분석하였다.

3 회의 윙게이트 테스트가 종료된 직후 2차 채혈을 하였으 며, 15 분이 경과되었을 때, 식초군(Brown-rice vinegar: BRV) 에게는 $\mathrm{pH}$ 2.93의 현미식초 $50 \mathrm{ml}$ 을 1 차 증류수에 4 배 희석하 여 섭취시켰다[30]. 윙게이트 테스트 직후 섭취하지 않은 이유 는 예비실험 시 나타난 구토증상을 제거하기 위함이었다. 섭 취한 현미식초의 초산함량은 최대 $4.55 \%$ 이다[18]. 또한 대조 군(Control: $\mathrm{CON}$ )에게는 동일한 양의 수분을 섭취하도록 하 였다. 식초의 강한 향의 특성상 교차분석법(Cross-over design)만을 실시하였으며, 1 주일 간격으로 동일한 피험자를 대 상으로 하였다. 또한 운동 후 30 분, 60 분, 그리고 120 분에 각각 채혈을 실시하였다. 채혈시기와 동일하게 호흡수, 산소포화 도, 심박수를 측정하였다. 호흡수는 누운 상태에서 피험자의 눈을 감게 하고 안면부에서 입과 코의 상단부에서 $10 \mathrm{~cm}$ 떨어 진 곳에 $10 \mathrm{~cm} \times 10 \mathrm{~cm}$ 의 유산지를 위치한 후 1 회의 움직임이 있을 때마다 카운터계(RS-4, Orion counter, Korea)를 이용하 여 1 분간의 횟수를 기록하였다. 심박수와 산소포화도 $\left(\mathrm{SpO}_{2}\right)$ 는 산소포화도측정기(Oxy9, Bionet, Korea)의 의료용 전극(WA101 , 메디니스(주), 대한민국)을 오른손 검지에 장착하여 실시 하였다.

\section{혈액분석}

채취된 혈액은 즉시 $1.5 \mathrm{ml}$ 의 Eppendorf tube에 옮겨 혈 중 글루코스와 젖산을 생화학자동분석기(YSI 2300 plus, YSI institute, USA)를 사용하여 분석하였다. 또한 혈액의 수소이 온농도를 분석하기 위하여 $\mathrm{pH}$ meter (SP701, Suntex, USA) 를 사용하였다. 나머지 혈액은 Serum separation tube에 옮 겼으며, 초고속원심분리기(비전과학, 대한민국)을 이용하여 $2,000 \times g$ 에서 15 분간 원심분리하여 상청액을 분리 후 분석시 까지 $-80^{\circ} \mathrm{C}$ 냉동고(Sanyo, Japan)에서 보관하였다. 유리지방

Table 1. Physical characteristics of the subjects

\begin{tabular}{cccccc}
\hline Age $(\mathrm{yr})$ & Height $(\mathrm{cm})$ & Body weight $(\mathrm{kg})$ & BMI $\left(\mathrm{kg} / \mathrm{m}^{2}\right)$ & WHR $(\%)$ & HRmax $(\mathrm{bpm})$ \\
\hline $24.35 \pm 1.72$ & $174.71 \pm 5.41$ & $67.29 \pm 8.61$ & $22.01 \pm 2.21$ & $0.83 \pm 0.03$ & $195.57 \pm 1.72$ \\
\hline
\end{tabular}

Values are mean \pm standard deviation $(\mathrm{M} \pm \mathrm{SD})$.

$\mathrm{n}=7$.

BMI: body mass index; WHR: waist to hip ratio; HRmax: heart rate maximum 
산은 효소법을 이용하여 분석하였다. 우선 혈청 $50 \mu 1$ 를 NEFAzyme (Shinyang, Korea) 용액 I $400 \mu 1$ 과 잘 혼합하여 $37^{\circ} \mathrm{C}$ 에서 5분간 반응시킨 후 용액 II $200 \mu 1$ 를 넣고 다시 $37^{\circ} \mathrm{C}$ 에서 5 분간 반응시켰다. 그 후 분광광도계(UV-1201, Shimadzu, Japan) 맹검을 대조로 파장 $555 \mathrm{~nm}$ 에서 검체의 흡광도를 읽은 후 표준액의 흡광도 및 농도를 이용하여 검체 의 농도를 구하였다. 암모니아는 분석용 킷(Sigma, USA)를 사용하여 분석하였다. 요약하면, 제단백시약 $40 \mathrm{ml}$ 와 혈액 샘플 $1.0 \mathrm{ml}$ 를 잘 혼합한 후 $2,500 \mathrm{rpm}$ 에서 5 분간 원심분리 기(비젼과학, 대한민국)를 이용하여 원심분리한 후 발색시약 을 넣고 혼합하였다. 그 후 $37^{\circ} \mathrm{C}$ 에서 20 분간 방치 후 파장 $630 \mathrm{~nm}$ 에서 분광광도계를 이용하여 흡광도를 계산하였다. 코티졸은 원심분리 후 상청액을 cortisol $\mathrm{Ab}$ 가 코팅된 검사 튜브에 검체를 $25 \mu \mathrm{l}$ 첨가한 후, ${ }^{125} \mathrm{I}$ cortisol (DPC, USA)을 $1.0 \mathrm{ml}$ 씩 다시 첨가하고 혼합한 후 $37^{\circ} \mathrm{C}$ 의 온도로 45 분간 반 응시켰으며, 이러한 과정이 종료되면 튜브에 있는 내용물을 완전히 흡입한 후 $\gamma$-counter (Cobra 5010 II, Quantum, USA)를 이용하여 분석하였다.

\section{자료처리}

피험자의 신체적 특징은 평균과 표준편차로 표기하였으며, 그 이외의 자료는 평균과 표준오차로 표기하였다[9]. 통계는 윈도우즈용 통계프로그램인 SPSS $14.0 \mathrm{~K}$ 를 사용하였다. 심폐 기능과 혈중 에너지 기질의 변화를 살펴보기 위하여 $2 \times 5$ (집단 $2 \times$ 시기 $5[0,3,30,60,120$ 분 $])$ 의 검정을 위하여 이원반복분산 분석을 실시하였고, 유의차가 있을 경우에 일원분산분석을 실 시한 후 사후검정으로서 Tukey법을 사용하였다. 윙게이트 테 스트의 집단 내 회복율을 알아보기 위하여 3 차시기와 4 차시기 의 students' paired $t$-test를 실시하였으며, 집단 간 회복율의 차이분석을 위해 students' unpaired $t$-test를 수행하였다. 모 든 차의 유의성은 $\mathrm{p}<0.05$ 이하로 설정하였다.

\section{결 과}

\section{심폐기능의 변화}

3 회의 반복적인 윙게이트 테스트 전후와 2 시간 동안의 회복 시에 나타난 심폐기능의 변화는 Table 2 와 같다. 호흡수는 윙 게이트 테스트 전에 비하여 직후에 유의하게 증가하였으며 $(\mathrm{p}<0.05)$, 이후 회복기 동안에 점차 감소하여 2 시간이 경과하 기까지 점차 회복하였다. 그러나 집단 간 유의차는 없었다. 산소포화도는 집단 및 시기간 모두 유의한 차이가 나타나지 않았다. 심박수는 운동 직후에 유의하게 증가하였다 $(\mathrm{p}<0.05)$. 또한 두 집단 모두 운동 직후에 비하여 회복기에 유의하게 낮았다( $\mathrm{p}<0.05)$. 그러나 집단간 유의차는 없었다.

\section{혈중 에너지 기질의 변화}

윙게이트 테스트 전후와 회복기의 혈중 에너지 기질의 변화 는 Fig. 1 과 같다. 혈중 글루코스(A)의 집단 간 차이는 운동 후 회복기 120 분에 $\mathrm{CON}$ 이 BRV에 비하여 유의하게 낮았다 $(\mathrm{p}<0.05)$. 혈중 유리지방산(B)의 집단 간 차이는 운동 후 회복 기 60 분과 120 분에 $\mathrm{BRV}$ 가 $\mathrm{CON}$ 에 비하여 유의하게 높았다 $(\mathrm{p}<0.05)$. 혈중 암모니아 $(\mathrm{C})$ 와 젖산 $(\mathrm{D})$ 은 운동 후 회복기 60 분 과 120 분에 $\mathrm{BRV}$ 가 $\mathrm{CON}$ 에 비하여 유의하게 낮았다 $(\mathrm{p}<0.05)$. 혈중 $\mathrm{pH}(\mathrm{E})$ 와 코티졸 $(\mathrm{F})$ 는 운동 후 회복기 전기간에 걸쳐 집단 간 유의한 차이가 없었다.

\section{윙게이트 파워의 변화}

3 회의 반복적인 윙게이트 테스트와 2시간의 휴식 후 실시한 4 회째의 윙게이트 파워의 변화는 Table 3과 같다. 전체 조사항 목 모두 3회의 반복적인 윙게이트 테스트에 의해 점차 감소하 였다. 평균파워의 회복 량은 $\mathrm{CON}$ 과 $\mathrm{BRV}$ 모두 유의하게 증가 하는 것으로 나타났으나 $(\mathrm{p}<0.05)$, 집단 간 회복 량과 회복 율은 유의한 차이가 없었다. 최대파워의 회복 량은 $\mathrm{CON}$ 과 $\mathrm{BRV}$

Table 2. Changes of $\mathrm{BF}, \mathrm{SpO}_{2}$, and $\mathrm{HR}$ at the pre-, post-Wingate test and recovery periods

\begin{tabular}{|c|c|c|c|c|c|}
\hline & \multicolumn{5}{|c|}{ Time (min) } \\
\hline & \multicolumn{2}{|c|}{ Wingate test } & \multicolumn{3}{|c|}{ Recovery periods } \\
\hline & 0 & 3 & 30 & 60 & 120 \\
\hline \multicolumn{6}{|c|}{ Breath frequency (BF, times/min) } \\
\hline $\mathrm{CON}$ & $18.99 \pm 2.33$ & $30.86 \pm 2.10^{\mathrm{a}}$ & $23.14 \pm 1.51$ & $20.29 \pm 2.58$ & $19.56 \pm 1.79$ \\
\hline BRV & $18.14 \pm 2.32$ & $28.29 \pm 2.35^{\mathrm{a}}$ & $21.43 \pm 2.18$ & $17.14 \pm 1.51$ & $18.86 \pm 2.03$ \\
\hline \multicolumn{6}{|c|}{ Oxygen saturation (SpO2, \%) } \\
\hline CON & $98.71 \pm 0.80$ & $98.12 \pm 0.89$ & $97.51 \pm 0.73$ & $97.34 \pm 0.89$ & $97.29 \pm 0.66$ \\
\hline BRV & $97.86 \pm 0.83$ & $96.86 \pm 0.95$ & $96.29 \pm 1.04$ & $95.86 \pm 1.63$ & $97.88 \pm 0.70$ \\
\hline \multicolumn{6}{|c|}{ Heart rates $(\mathrm{HR}, \mathrm{bpm})$} \\
\hline $\mathrm{CON}$ & $76.00 \pm 2.89$ & $123.14 \pm 1.92^{\mathrm{a}}$ & $92.71 \pm 3.35^{\mathrm{b}}$ & $86.57 \pm 3.29^{b}$ & $73.43 \pm 2.77^{6}$ \\
\hline BRV & $78.16 \pm 2.71$ & $116.14 \pm 3.50^{\mathrm{a}}$ & $93.71 \pm 1.78^{b}$ & $90.58 \pm 2.23^{b}$ & $77.86 \pm 2.98^{b}$ \\
\hline
\end{tabular}

Values are $\mathrm{M} \pm \mathrm{SE}$.

$\mathrm{CON}$ : control trial; BRV: brown-rice vinegar trial

${ }^{a}$ significantly different from the pre-exercise; ${ }^{b}$ significantly different from the post-exercise at $p<0.05$, respectively. 

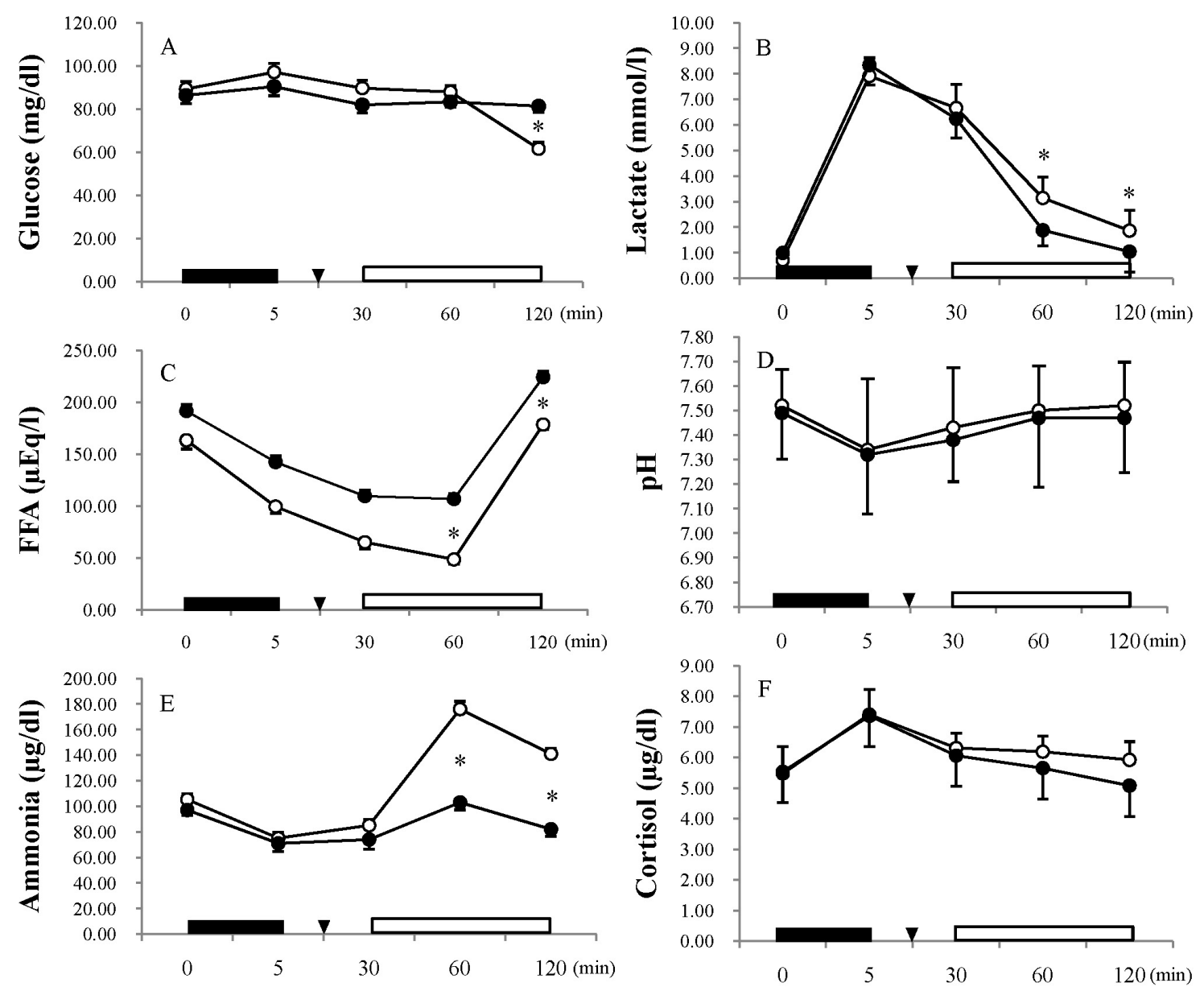

Fig. 1. Changes of blood substrates at the pre-, post-Wingate exercise and the recovery periods for $2 \mathrm{hr}$. Bars are mean $\pm S E$. $\bigcirc$ : control trial; $\bullet$ : brown-rice vinegar trial; $\mathbf{\nabla}$ : ingestion; $\mathbf{\square}$ : Wingate exercise; $\square$ : recovery. ${ }^{*}$ Means significance between groups at the same time points at $p<0.05$.

Table 3. Changes of the Wingate test powers

\begin{tabular}{|c|c|c|c|c|c|c|}
\hline & & \multicolumn{4}{|c|}{ Repeated Wingate test } & \multirow{2}{*}{ Recovery rate $(\%)$} \\
\hline & & 1st & 2nd & 3rd & 4th & \\
\hline \multirow{2}{*}{$\begin{array}{l}\text { Mean power } \\
\text { (MP, Watts) }\end{array}$} & $\mathrm{CON}$ & $566.43^{\mathrm{a}} \pm 9.84^{\mathrm{a}}$ & $375.71^{\mathrm{a}} \pm 8.43^{\mathrm{a}}$ & $319.14^{*} \pm 7.70^{\mathrm{a}}$ & $545.86^{*} \pm 9.95^{\mathrm{a}}$ & $171.04^{\S} \pm 3.98^{\S}$ \\
\hline & $\mathrm{BRV}$ & $546.00^{\mathrm{a}} \pm 6.16^{\mathrm{a}}$ & $401.71^{\mathrm{a}} \pm 6.14^{\mathrm{a}}$ & $328.86^{*} \pm 6.01^{\mathrm{a}}$ & $580.71^{*} \pm 8.13^{\mathrm{a}}$ & $176.59^{\S} \pm 3.55^{\S}$ \\
\hline \multirow{2}{*}{$\begin{array}{l}\text { Peak power } \\
\text { (PP, Watts) }\end{array}$} & $\mathrm{CON}$ & $702.00^{\mathrm{a}} \pm 9.46^{\mathrm{a}}$ & $463.29^{\mathrm{a}} \pm 9.14^{\mathrm{a}}$ & $333.86^{*} \pm 7.71^{\mathrm{a}}$ & $615.14^{*} \pm 9.25^{\mathrm{a}}$ & $184.25^{\S} \pm 2.61^{\S}$ \\
\hline & $\overline{B R V}$ & $646.71^{\mathrm{a}} \pm 8.89^{\mathrm{a}}$ & $496.14^{\mathrm{a}} \pm 8.78^{\mathrm{a}}$ & $364.29^{*} \pm 8.53^{\mathrm{a}}$ & $698.12^{*} \pm 9.77^{\mathrm{a}}$ & $191.64^{\S} \pm 3.39^{\S}$ \\
\hline \multirow{2}{*}{$\begin{array}{l}\text { MP/body weight } \\
\text { (Watts } / \mathrm{kg} \text { ) }\end{array}$} & $\mathrm{CON}$ & $8.32^{\mathrm{a}} \pm 0.64^{\mathrm{a}}$ & $5.52^{\mathrm{a}} \pm 0.71^{\mathrm{a}}$ & $4.72^{*} \pm 0.83^{\mathrm{a}}$ & $8.01^{*} \pm 0.72^{\mathrm{a}}$ & $169.70^{\S} \pm 4.65^{\S}$ \\
\hline & $\overline{\mathrm{BRV}}$ & $8.34^{\mathrm{a}} \pm 0.55^{\mathrm{a}}$ & $6.05^{\mathrm{a}} \pm 0.60^{\mathrm{a}}$ & $4.98^{*} \pm 0.85^{\mathrm{a}}$ & $8.72^{*} \pm 0.36^{\mathrm{a}}$ & $175.10^{\S} \pm 3.68^{\S}$ \\
\hline \multirow{2}{*}{$\begin{array}{l}\text { PP/body weight } \\
\text { (Watts/kg) }\end{array}$} & $\mathrm{CON}$ & $10.31^{\mathrm{a}} \pm 0.72^{\mathrm{a}}$ & $6.76^{\mathrm{a}} \pm 0.71^{\mathrm{a}}$ & $4.99^{*} \pm 0.81^{\mathrm{a}}$ & $9.07^{*} \pm 0.72^{\mathrm{a}}$ & $181.76^{\S} \pm 4.37^{\S}$ \\
\hline & $\overline{\mathrm{BRV}}$ & $9.87^{\mathrm{a}} \pm 0.64^{\mathrm{a}}$ & $7.46^{\mathrm{a}} \pm 0.53^{\mathrm{a}}$ & $5.51^{*} \pm 0.80^{\mathrm{a}}$ & $10.46^{*} \pm 0.52^{\mathrm{a}}$ & $198.83^{\S} \pm 3.56^{\S}$ \\
\hline \multirow{2}{*}{$\begin{array}{l}\text { Total works } \\
\text { (Kjouls) }\end{array}$} & $\mathrm{CON}$ & $16.99^{\mathrm{a}} \pm 1.71^{\mathrm{a}}$ & $11.27^{\mathrm{a}} \pm 1.46^{\mathrm{a}}$ & $9.57^{*} \pm 1.37^{\mathrm{a}}$ & $16.62^{*} \pm 1.87^{\mathrm{a}}$ & $173.67^{\S} \pm 2.33^{\S}$ \\
\hline & $\overline{\mathrm{BRV}}$ & $16.38^{\mathrm{a}} \pm 1.41^{\mathrm{a}}$ & $12.05^{\mathrm{a}} \pm 1.06^{\mathrm{a}}$ & $9.87^{*} \pm 1.04^{\mathrm{a}}$ & $17.42^{*} \pm 1.86^{\mathrm{a}}$ & $176.49^{\S} \pm 2.61^{\S}$ \\
\hline
\end{tabular}

Values are $\mathrm{M} \pm \mathrm{SE}$.

CON: control trial; BRV: brown-rice vinegar trial

*significantly different between $3 \mathrm{rd}$ and 4 th trials within group; ${ }^{\S}$ significantly different between groups at $p<0.05$.

모두 유의하게 증가하는 것으로 나타났으며 $(\mathrm{p}<0.05)$, 집단 간 차이가 나타났다 $(\mathrm{p}<0.05)$. 체중 당 평균파워의 회복 량은 $\mathrm{CON}$ 과 $\mathrm{BRV}$ 모두 유의하게 증가하는 것으로 나타났으나 $(\mathrm{p}<0.05)$,
회복 량과 회복 율의 집단 간 유의한 차이가 없었다. 체중당 최대파워의 회복 량은 $\mathrm{CON}$ 과 $\mathrm{BRV}$ 모두 유의하게 증가하는 것으로 나타났으며 $(\mathrm{p}<0.05)$, 회복 율은 $\mathrm{CON}$ 에 비하여 $\mathrm{BRV}$ 가 
유의하게 높았다 $(\mathrm{p}<0.05)$. 총일량의 회복 량은 $\mathrm{CON}$ 과 $\mathrm{BRV}$ 모두 유의하게 증가하는 것으로 나타났으나( $\mathrm{p}<0.05)$, 회복 량 과 회복 율의 집단 간 유의차가 없었다.

\section{고 찰}

본 연구는 반복적이고 탈진적인 고강도의 윙게이트 테스트 에 의하여 피로를 유발한 후 식초 섭취가 회복기의 에너지 기질 이용에 미치는 영향을 조사하고자 신체적으로 건강한 남자 대학생 7명을 대상으로 수행하였으며, 윙게이트 파워의 변화와 혈액성분을 분석하였다. 본 연구에서 사용한 윙게이트 테스트는 단시간에 최대파워에 도달하게 되고, 무산소성 해당 과정을 통해 젖산의 축적과 근피로를 유발하는데 적절한 방법 이다[6]. 실제로 최근의 연구에서도 근피로를 유발하는 연구방 법으로 선택하고 있으며[2,39], 완전한 탈진을 유도하기 위하 여 고강도 운동의 적용방법으로서 3회의 반복을 응용하여 적 용하였다[3]. 또한 반복적인 윙게이트 테스트는 일회성 윙게이 트 테스트에 비하여 운동 후 안정시까지의 회복시간이 더욱 요구되므로 120 분까지를 회복기로 설정하였다[25].

우선, 본 연구의 Table 2에 나타난 윙게이트 테스트 전후와 회복기의 호흡수, 산소포화도, 그리고 심박수는 두 집단간 차 이가 나타나지 않았다. 산소포화도는 실험 조건이 운동 전후 와 회복기 모두 저산소 혹은 저기압 환경으로 실험환경을 통 제하지 않았기 때문에 변화하지 않았을 것으로 판단되며[29], 만성폐색성폐질환자의 정상범위[32]로 인정되는 것보다 높게 유지되었으므로 섭취한 식초에 의해 변화하지 않았다고 할 수 있다. 오히려, $\mathrm{CON}$ 과 BRV 모두 집단 간 유의한 차이 없이 운동직후의 변화 이후에 회복 120 분 동안 안정상태로 회복되 었다는 것은 동일한 운동강도가 부하되었다는 점을 시사한다 고 생각된다.

혈중 글루코스 농도는 운동 시 항상성을 유지하기 위하여 안정상태의 범위를 유지하는 것이 일반적이며, 고강도의 탈진 적인 운동 시에는 증가하는 것으로 나타난다[21]. 본 연구에서 도 글루코스 농도(Fig. $1 \mathrm{~A})$ 는 운동 직후 소량 상승하는 것으로 나타났으나, 유의차는 없었다. 그러나 회복기 120 분에 $\mathrm{CON}$ 이 유의하게 낮은 것으로 나타났다. 이는 윙게이트 테스트 의한 영향이라기 보다는 오히려 운동 2시간 전에 섭취한 식사가 소화·흡수되었으며[14], BRV의 경우 운동 직후 섭취한 식초의 초산이 탄수화물의 산화를 억제시켰기 때문이라 생각된다[9]. 또한 식초섭취에 의하여 포만감이 연장되었으며, 식후의 글루 코스 농도 역시 높게 유지되었다는 결과를 고려할 때 고강도 의 운동 후 초산이 함유되어 있는 식초의 섭취는 탄수화물 농도의 유지에 효과적이라 사료된다[17]. 실제로 식초를 섭취 한 이후에 최대산소섭취량의 $60 \%$ 강도로 트레드밀 운동을 부
하한 결과 탄수화물의 사용이 소량 억제되는 연구결과도 나타 나고 있다[30].

일반적으로 탈진적인 고강도의 운동을 실시하게 되면 분해 된 젖산에 의해 산성화가 유발된다[7]. 그러나 본 연구의 결과 (Fig. 1B)에서 나타난 젖산 농도가 회복기 60 분과 120 분에 BRV 에 비하여 $\mathrm{CON}$ 에서 높음에도 불구하고 $\mathrm{pH}$ (Fig. 1D)는 $\mathrm{CON}$ 과 BRV 모두 유의한 차이를 보이지 않았다. 이러한 결과는 식초 섭취와 지구성 운동능력을 조사한 연구에서 보면[30], 식 초 섭취군에서 운동 중 $\mathrm{pH}$ 가 대조군에 비하여 유의하게 낮은 것으로 나타나 본 연구의 $\mathrm{pH}$ 가 차이가 없는 것과는 다소 차이 가 나타난다. 이는 본 연구에서는 부하한 운동 강도가 탈진적 인 고강도 운동이었으나, 회복기에 나타난 변화를 알아보고자 운동 직후부터 신체활동을 최대한 제한하였고, 120 분간의 회 복시간 동안에 젖산의 지속적인 회복이 이루어졌기 때문이라 생각된다. 또한 젖산의 결과를 볼 때, 섭취한 식초 성분 중 대부분이 초산이었다는 점을 고려한 연구 즉, 실험쥐를 20시 간 절식시킨 후 식이에 초산을 혼합하여 섭취시킨 결과 실험 군이 대조군에 비하여 유의한 수준에서 젖산이 식후 8시간까 지 낮게 나타났으며, 그 이유로서 고농도의 cAMP, 낮은 X-5-P, PFK-2/F26Bpase의 증가로 인한 F-2,6-P2의 감소 때문이라는 보고를 볼 때, $\mathrm{BRV}$ 는 식초에 의하여 젖산의 생성이 감소하였 다고 생각된다[15,30]. 실제로 식초의 주성분인 초산 섭취에 의하여 탄수화물 산화가 억제되는 결과가 제시되고 있다[33]. 또한 식초에 의해 억제된 탄수화물 산화와 함께 유리지방산의 변화는 운동 전후에는 집단간 차이가 나타나지 않았으나, 회 복기 60 분과 120 분에 $\mathrm{BRV}$ 가 높은 것으로 나타났다(Fig. 1C). 본 연구진의 선행연구에서도 식초 섭취에 의하여 유리지방산 농도가 높게 유지되는 것으로 보고한바 있다[22,30]. 이는 초산 의 지방합성 억제 작용 때문이며, acetate $+\mathrm{CoA}+\mathrm{ATP} \Leftrightarrow$ acetyl-CoA + AMP + pyrophosphate의 과정이 발생되므로 [15], AMP-activated protein kinase의 활성과 CPT-1 mRNA 의 증가[26], 인슐린 농도의 감소[19] 등의 결과가 작용하였으 리라 생각된다. 따라서 운동과 관련된 식초의 효과는 탄수화 물 산화를 효과적으로 억제함으로서 지방산화를 유지하는 결 과가 나타난다는 점을 시사하고 있다.

한편, 최대 무산소성 운동능력을 향상시키기 위해서 저장 에너지원의 효과적인 이용뿐만 아니라 피로요인을 최소화시 키는 것은 매우 중요한 요소이다. 혈중 암모니아는 단백질의 이화작용에 의해 나타나며, 암모니아 농도의 상승은 중추신경 계 피로를 유발하여 운동능력을 저하시키게 되고[5], 간에서의 제거능이 저하하고 뇌와 같은 기관에 노출됨으로 인하여 독성 을 유발하게 된다[37]. 그러나 일반적으로 수소이온농도가 5.0 이하로 나타나면 암모니아 생성이 감소하며[36], 실제로 $\mathrm{pH}$ 3.0 인 목초액에 의해 암모니아 농도가 감소하였다고 보고[22] 
와 지구성 운동시 목초액 섭취에 의하여 혈중 암모니아 농도 가 유의하게 저하한 연구결과가 있다[21]. 본 연구에서도 섭취 한 식초의 $\mathrm{pH}$ 가 2.93으로 매우 낮았으며, 혈중 암모니아 농도 역시 운동 후 회복기에 $\mathrm{CON}$ 에 비하여 유의하게 낮게 유지된 결과는 젖산이 최대강도의 운동 중 급격하게 상승하는데 반하 여 암모니아는 고강도의 운동 중 상승이 유발되지 않는다는 제언과 동일하다[8]. 이는 운동 후 식초의 섭취는 운동 후에 의해 증가하는 암모니아 상승과 관련된 피로회복에 도움이 될 수 있다는 점을 시사하고 있다.

본 연구에서 분석한 코티졸은 스트레스 호르몬의 일종으로 서 체내에서 이화작용을 증가시키며, 운동강도와 운동시간에 따라 증가하는 것으로 알려져 있다. 본 연구에서는 코티졸의 상승은 두 집단 모두 운동 직후에 이루어졌으나, 회복기에 집 단 간 차이가 없이 회복하는 경향을 보였다. 이는 섭취한 식초 에 의한 영향은 나타나지 않은 것으로 생각되며, 탄수화물 섭 취에 의하여 글루코스 농도가 높게 유지되었고 코티졸 농도가 낮게 유지되었다는 결과에 착안해볼 때[12], 본 연구에서 운동 후 회복기 120 분에 BRV에서 글루코스 농도가 높게 유지되었 다는 것과 관련이 있을 것이라 예상하며, 추후 지속적인 연구 가 필요하다고 생각된다.

한편, 120 분간의 휴식이 끝난 후 다시 1 회의 윙게이트 테스 트를 부하하였을 때 나타난 결과를 보면, 평균파워에서는 유 의한 차이가 없었으나, 최대파워와 체중당 최대파워에서 BRV 가 유의하게 높은 회복율을 나타내었다(Table 3). 이러한 결과 는 위에서 제시된 바와 마찬가지로 식초의 초산성분에 의한 피로회복의 촉진과 회복기 중의 탄수화물 산화 억제로 인하여 나타난 결과라 판단된다 $[21,22,33]$. 따라서 탈진적인 고강도 운 동 후 식초 섭취는 최대파워능의 회복에 도움을 주어 반복적 인 경기가 이루어지는 종목에 도움을 줄 수 있다고 생각된다. 따라서, 반복적인 윙게이트 테스트에 의해 유도된 탈진 이후 의 식초 섭취는 피로물질의 제거 촉진과 회복기 탄수화물 산 화의 억제를 유도함으로써 에너지원 회복에 도움을 주며, 반 복적인 경기가 이루어지는 종목에 효과적으로 이용될 수 있는 영양보조물로서의 가능성이 있다고 사료된다.

\section{References}

1. Aleman, K. B. and M. C. Meyers. 2010. Mountain biking injuries in children and adolescents. Sports Med. 40, 77-90.

2. Arent, S. M., M. M. Senso, D. L. Golem, and K. H. McKeever. 2010. The effects of theaflavin-enriched black tea extract on muscle soreness, oxidative stress, inflammation, and endocrine responses to acute anaerobic interval training: a randomized, double-blind, crossover study. J. Int. Soc. Sports Nutr. 7, 11-20.

3. Arroyo-Morales, M., N. Olea, C. Ruiz, D. del Castilo Jde, M. Martinez, C. Lorenzo, and L. Diaz-Rodriguez. 2009.
Massage after exercise-responses of immunologic and endocrine markers: a randomized single-blind place-controlled study. J. Strength Cond. Res. 23, 638-644.

4. Baldari, C., L. Di Luigi, S. G. Silva, M. C. Gallotta, G. P. Emerenziani, C. Pesce, and L. Guidetti. 2007. Relationship between optimal lactate removal power output and Olympic triathlon performance. J. Strength Cond. Res. 21, 1160-1165.

5. Banister, E. W. and B. J. Cameron. 1990. Exercise-induced hyperammonemia: peripheral and central effects. Int. J. Sports Med. 11, 129-142.

6. Bar-Or, O. 1987. The Wingate anaerobic test. An update on methodology, reliability and validity. Sports Med. 4, 381-394.

7. Böning, D. and N. Maassen. 2008. Point: Lactic acid is the only physicochemical contributor to the acidosis of exercise. J. Appl. Physiol. 105, 358-359.

8. Calvert, L. D., M. C. Steiner. M. D. Morgan, and S. J. Singh. 2010. Plasma ammonia response to incremental cycling and walking tests in COPD. Respir. Med. 104, 675-681.

9. Chioléro, R., P. Mavrocordatos, P. Burnier, M. C. Cayeux, C. Schindler, E. Jéquier, and L. Tappy. 1993. Effects of infused sodium acetate, sodium lactate, and sodium beta-hydroxybutyrate on energy expenditure and substrate oxidation rates in lean humans. Am. J. Clin. Nutr. 58, 608-613.

10. Cooke, M. B., E. Rybalka, A. D. Williams, P. J. Cribb, and A. Hayes. 2009. Creatine supplementation enhances muscle force recovery after eccentrically-induced muscle damage in healthy individuals. J. Int. Soc. Sports Nutr. 6, 13-14.

11. Davis, J. M., C. J. Carlstedt, S. Chen, M. D. Carmichael, and E. A. Murphy. 2010. The Dietary Flavonoid Quercetin Increases VO2max and Endurance Capacity. Int. J. Sport Nutr. Exerc. Metab. 20, 56-62.

12. de Sousa, M. V., K. Madsen, H. G. Simões, R. M. Pereira, C. E. Negrão, R. Z. Mendonça, L. Takayama, R. Fukui, and M. E. da Silva. 2010. Effects of carbohydrate supplementation on competitive runners undergoing overload training followed by a session of intermittent exercise. Eur. J. Appl. Physiol. 109, 507-516.

13. de Vries, J. M., M. L. Hagemans, J. B. Bussmann, A. T. van der Ploeg, and P. A. van Doorn. 2010. Fatigue in neuromuscular disorders: focus on Guillain-Barré syndrome and Pompe disease. Cell Mol. Life Sci. 67, 701-713.

14. Erdmann, J., S. Tholl, and V. Schusdziarra. 2010. Effect of carbohydrate- and protein-rich meals on execise-induced activation of lipolysis in obese subjects. Horm. Metab. Res. 42, 290-294.

15. Fushimi, T. and Y. Sato. 2005. Effect of acetic acid feeding on the circadian changes in glycogen and metabolites of glucose and lipid in liver and skeletal muscle of rats. Br. J. Nutr. 94, 714-719.

16. Fushimi, T., K. Suruga, Y. Oshima, M. Fukiharu, Y. Tsukamoto, and T. Goda. 2006. Dietary acetic acid reduces serum cholesterol and triacylglycerols in rats fed a cholesterol-rich diet. Br. J. Nut. 95, 916-924.

17. Hlebowicz, J., S. Lindstedt, O. Björgell, P. Höglund, L. O. Almér, and G. Darwiche. 2008. The botanical integrity of 
wheat products influences the gastric distention and satiety in healthy subjects. Nutr. J. 27, 7-12.

18. Jeong, Y. J., J. H. Seo, S. H. Jung, S. R. Shin, and K. S. Kim. 1998. The quality comparison of uncleaned rice vinegar by two stages fermentation with commercial uncleaned rice vinegar. Korean J. Postharvest Sci. Technol. 5, 374-380.

19. Johnston, C. S. and A. J. Buller. 2005. Vinegar and peanut products as complementary foods to reduce postprandial glycemia. J. Am. Diet Assoc. 105, 1939-1942.

20. Johnston, C. S., A. M. White, and S. M. Kent. 2008. A preliminary evaluation of the safety and tolerance of medicinally ingested vinegar in individuals with type 2 diabetes. J. Med. Food 11, 179-183.

21. Jung, S. Y, H. R. Jeon, S. Lee, S. Ryu, H. K. Kim, and Y. B. Kim. 2009. The effects of a pyroligneous liquor on ammonia, glycogen and exercise performance in endurance trained rat. Korean J. Phy. Edu. 48, 539-544.

22. Kang, J. S., S. H. Kim, P. G. Kim, D. W. Lee, and S. Ryu. 2009. Differences of wood vinegar ingestion and exercise training on blood lipids, MDA, and SOD activities in rats. J. Life Sci. 19, 1190-1199.

23. Kwon, Y. S., R. A. Robergs, L. R. Kravitz, B. A. Gurney, C. M. Mermier, and S. M. Schneider. 2010. Palm cooling delays fatigue during high intensity bench press exercise. Med. Sci. Sports Exerc. 42, 1557-1565.

24. Martin, N. A., R. F. Zoeller, R. J. Robertson, and S. M. Lephart. 1998. The comparative effects of sports massage, active recovery, and rest in promoting blood lactate clearance after supramaximal leg exercise. J. Athl. Train. 33, 30-35.

25. Millar, P. J., M. Rakobowchuk, N. McCartney, and M. J. MacDonald. 2009. Heart rate variability and nonlinear analysis of heart rate dynamics following single and multiple Wingate bouts. Appl. Physiol. Nutr. Metab. 34, 875-883.

26. Moon, Y. J. and Y. S. Cha 2008. Effects of persimmon-vinegar on lipid metabolism and alcohol clearance in chronic alcohol-fed rats. J. Med. Food 11, 38-45.

27. Ostman, E., Y. Granfeldt, L. Persson, and I. Björck. 2005. Vinegar supplementation lowers glucose and insulin responses and increases satiety after a bread meal in healthy subjects. Eur. J. Clin. Nutr. 59, 983-988.

28. Roschel, H., B. Gualano, M. Marquezi, A. Costa, and A. H. Lancha. 2010. Creatine supplementation spares muscle glycogen during high intensity intermittent exercise in rats. J.
Int. Soc. Sports Nutr. 29, 6-12.

29. Rupp, T. and S. Perrey. 2009. Effect of severe hypoxia on prefrontal cortex and muscle oxygenation responses at rest and during exhaustive exercise. Adv. Exp. Med. Biol. 645, 329-334.

30. Ryu, S. and T. D. Kwon. 2009. Effects of brown-rice vinegar ingestion on energy metabolism during moderate intensity exercise. Korean J. Exer. Nutr. 13, 217-224.

31. Sale, C., B. Saunders, and R. C. Harris. 2009. Effect of beta-alanine supplementation on muscle carnosine concentrations and exercise performance. Amino Acids 39, 321-333.

32. Sanchez, F. F., M. M. Faganello, S. E. Tanni, P. A. Lucheta, C. R. Padovani, and I. Godoy. 2008. Relationship between disease severity and quality of life in patients with chronic obstructive pulmonary disease. Braz. J. Med. Biol. Res. 41, 860-865.

33. Smith, G. I., A. E. Jeukendrup, and D. Ball. 2007. Sodium acetate induces a metabolic alkalosis but not the increase in fatty acid oxidation observed following bicarbonate ingestion in humans. J. Nut. 137, 1750-1756.

34. Stroud, N. M. and C. L. Minahan. 2009. The impact of regular physical activity on fatigue, depression and quality of life in persons with multiple sclerosis. Health Qual. Life Outcomes 20, 68-77.

35. Van Schaftingen, E. and H. G. Hers. 1986. Purification and properties of phosphofructokinase 2-fructose 2,6-bisphosphatase from chicken liver and from pigeon muscle. Eur. J. Biochem. 159, 359-365.

36. Vince, A., M. Killingley, and O. M. Wrong. 1978. Effect of lactulose on ammonia production in a fecal incubation system. Gastroenterology 74, 544-549.

37. Wilkinson, D. J., N. J. Smeeton, and P. W. Watt. 2010. Ammonia metabolism, the brain and fatigue; revisiting the link. Prog Neurobiol. 91, 200-219.

38. Yu, F. R., Y. Liu, Y. Z. Cui, E. Q. Chan, M. R. Xie, P. P. McGuire, and F. H. Yu. 2010. Effects of a flavonoid extract from Cynomorium songaricum on the swimming endurance of rats. Am. J. Chin. Med. 38, 65-73.

39. Zupan, M. F., A. W. Arata, L. H. Dawson, A. L. Wile, T. L. Payn, and M. E. Hannon. 2009. Wingate Anaerobic Test peak power and anaerobic capacity classifications for men and women intercollegiate athletes. J. Strength Cond. Res. 23, 2598-2604. 
초록 : 고강도의 윙게이트 테스트 후 식초섭취에 의한 회복기의 에너지기질 변화 연구

송영주 · 류승필 ${ }^{1 *}$

(선문대학교 스포츠과학부, ${ }^{1}$ 경북대학교 레저스포츠학과)

본 연구에서는 탈진적인 고강도의 운동 후 현미식초 섭취에 의한 2시간에 걸친 회복기의 에너지기질 변화를 분석하고자 7명의 건강한 대학생을 대상으로 3회의 반복적인 윙게이트 테스트를 통하여 피로를 유발하고 15 분이 경과되었을 때 현미식초(brown-rice vinegar, BRV) 또는 물(control, $\mathrm{CON})$ 을 섭취시켰다. 채혈은 테스트 전, 후, 회복기 30 분, 60 분, 그리고 120 분에 각각 채혈하였으며, 혈중 글루코스, 젖산, 유리지방산, 암모니아, 그리고 코티 졸을 분석하였다. 회복 120 분이 경과되었을 때, 4 회째의 윙게이트 테스트를 실시하여 3 회째에 대한 회복율을 계 산하였다. 호흡수, 산소포화도, 그리고 심박수는 유의한 변화는 나타나지 않았다. 혈중 글루코스는 회복 120 분에 $\mathrm{CON}$ 이 BRV에 비하여 유의하게 낮았으며, 혈중 젖산과 암모니아 농도는 회복 60 분과 120 분에 BRV가 유의하게 낮았고, BRV에서 회복 60 분과 120 분에 유리지방산 농도가 유의하게 높았다. 윙게이트 테스트의 최대파워 회복 율과 체중당 최대파워의 회복 율은 BRV에서 유의한 증가가 나타났다. 이러한 결과는 탈진적인 고강도의 운동 후 현미식초의 섭취에 의해 피로의 회복이 촉진되며, 하루에 두 번 혹은 그 이상 개최되는 경기에 있어서도 효과 적인 영양보조물로 사용될 수 있다는 점을 시사한다. 